\title{
Comparison of botulinum neurotoxin type $A$ formulations in Asia
}

\section{Jürgen Frevert' \\ Ki Young Ahn² \\ Mee Young Park ${ }^{3}$ \\ Owen Sunga ${ }^{4}$}

'Merz Pharmaceuticals GmbH, Frankfurt, Germany; ${ }^{2}$ Dr. Ahn's Plastic and Aesthetic Surgical Clinic, Daegu, South Korea; ${ }^{3}$ Department of Neurology, Yeungnam University School of Medicine, Daegu, South Korea; ${ }^{4}$ Merz Asia Pacific, Singapore

Video abstract

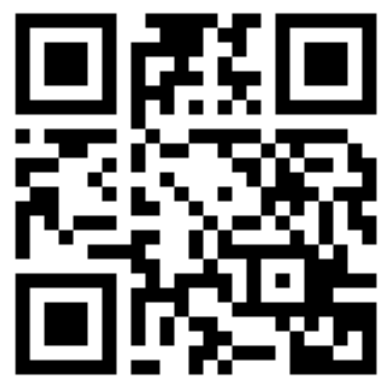

Point your SmartPhone at the code above. If you have a QR code reader the video abstract will appear. Or use: http://youtu.be/06uBSDQ0N60
Correspondence: Jürgen Frevert Merz Pharmaceuticals GmbH, Hermannswerder 15, 14473 Potsdam, Germany

Tel +493312300116

$\mathrm{Fax}+493312300199$

Email Juergen.Frevert@merz.de
This article was published in the following Dove Press journal: Clinical, Cosmetic and Investigational Dermatology

\begin{abstract}
Introduction: All protein-based therapeutics, such as botulinum neurotoxin type A (BoNT/A), are potentially immunogenic and can lead to anaphylaxis, autoimmunity, or diminished or complete absence of therapeutic efficacy, especially if administered repeatedly. Therefore, the protein quantity in BoNT/A products is an important consideration when selecting products for treatment. However, essential formulation data are not always publicly accessible.
\end{abstract}

Materials and methods: The neurotoxin protein content of products newly introduced in Asia, such as (listed alphabetically) Botulax ${ }^{\circledR}$, Meditoxin ${ }^{\circledR}$, Nabota $^{\circledR}$, and Relatox ${ }^{\circledR}$, was measured by sandwich enzyme-linked immunosorbent assay with antisera directed against BoNT/A compared to Xeomin ${ }^{\circledR}$.

Results: Compared to Xeomin with no inactive neurotoxin, although Botulax and Nabota contained 844 and 754 pg of neurotoxin protein, respectively, the percentage of inactive neurotoxin was calculated to be 103 and 81 , respectively, while the potency per pg of neurotoxin was 0.118 and $0.133 \mathrm{U}$, respectively. Meditoxin and Relatox had 575 and $578 \mathrm{pg}$ of neurotoxins, respectively, marginally higher than that of Xeomin, while the percentage of inactive neurotoxins was 38 and 33, respectively, and the potency per pg of neurotoxin was 0.174 and $0.173 \mathrm{U}$, respectively. However, Xeomin, which has $416 \mathrm{pg} /$ vial of purified neurotoxin and $0.240 \mathrm{U}$ of efficacy per pg of neurotoxin, has the lowest neurotoxin protein content and consequently the highest specific potency compared to the four Asian BoNT/A preparations in this study.

Conclusion: Although Botulax and Nabota had more neurotoxin than Xeomin in an equivalent volume, they contained greater amounts of inactive neurotoxin. In addition, although Meditoxin and Relatox had slightly more neurotoxin than Xeomin, both contained greater amounts of inactive neurotoxin.

Keywords: botulinum neurotoxin type A, purity, potency, immunogenicity, Asia

\section{Introduction}

Botulinum neurotoxin type A (BoNT/A) is a leading tool in the treatment of neuromuscular diseases and has also been used for cosmetic purposes for a long time. During immunogenic responses, "neutralizing" antibodies develop against the toxin, inhibiting the interaction between BoNT/A and its presynaptic membrane binding site, ${ }^{1-3}$ causing an inadequate or no response to BoNT/A. ${ }^{4}$ BoNT/A products, especially new toxin formulations, typically undergo rigorous evaluations for use as prescription-only medicines. Clinicians should, therefore, select less immunogenic, highly purified toxins to obtain successful results for long-term repeated treatments. ${ }^{5}$ 
New toxin formulations have recently emerged in Asia but investigations to quantify these neurotoxins such as their purity (defined as being complexing protein-free), the impact of their dose on efficacy, or adverse events, have been limited. ${ }^{6}$ Therefore, we analyzed the composition of the neurotoxin component of each product relative to Xeomin ${ }^{\circledR}$ using a sandwich enzyme-linked immunosorbent assay (ELISA) with antisera directed against the purified BoNT/A, to better understand these newer formulations. We seek to provide clinicians with valuable information to enable safe and effective treatment with BoNT/A.

\section{Materials and methods Materials}

The different protein and neurotoxin contents of Botulax ${ }^{\circledR}$ (Batch HUA 15133; Hugel Inc., Seoul, Korea), Innotox ${ }^{\circledR}$ (Batch LAE 1401; Medytox Inc., Seoul, Korea), Meditoxin ${ }^{\circledR}$ (Batch FAA 1587; Medytox Inc., Seoul, Korea), Nabota ${ }^{\circledR}$ (Batch 084962; Daewoong Pharmaceutical Co. Ltd., Seoul, Korea), Relatox ${ }^{\circledR}$ (Batch 0615; Microgen, Russia), as well as Xeomin (Batch 31149; Merz Pharmaceuticals GmbH, Reinheim, Germany), were measured using a sandwich ELISA with antisera (Table 1). Because the manufacturing process for a biologic therapeutic should be consistent and every batch should be representative, the batches were, therefore, selected arbitrarily. The batches were purchased from a South Korean pharmacy (ShinOn Pharmacy Co. Ltd., Seoul, South Korea). Care was taken to transport and store the samples at $2^{\circ} \mathrm{C}-8^{\circ} \mathrm{C}$, except samples of Xeomin that can be stored at room temperature. The composition of the neurotoxin elements of each product compared to those of Xeomin was then analyzed in duplicate to determine the mean amount of neurotoxin protein.

\section{Methods}

All analyses were carried out with an ELISA approved by the FDA (Food and Drug Administration, Silver Spring, MD, USA) and several other health authorities. The facility in which samples were analyzed was inspected by the FDA regularly and fulfilled current good manufacturing practice requirements.

For incubation, PBS $+0.1 \%$ bovine serum albumin (solution 1) and PBS $+6 \%$ gelafusal (Serumwerke Bernburg, Bernburg, Germany; solution 2) (Merck, Darmstadt, Germany, or Riedel-de-Haen, Seelze, Germany) were used. Additional reagents included O-phenylenediamine dihydrochloride (Sigma-Aldrich Corp, St. Louis, MO, USA) and horse anti-serum reacting with the neurotoxin complex of BoNT/A (UK National Institute for Biological Standards and Control, NIBSC). Following a modified protocol, ${ }^{7}$ the $150 \mathrm{kDa}$ neurotoxin purified from the "Hall Strain", C. botulinum type A, strain ATCC 3502, was confirmed by western blot as complexing protein-free and detoxified by $0.4 \%$ formaldehyde treatment to produce the nontoxic antigen for antibody preparation. Complexing proteins (excluding the botulinum neurotoxin protein) were prepared as previously published. ${ }^{8}$ The purified toxin was dialyzed against $50 \mathrm{mM}$ TRIS (tris[hydroxymethyl] aminomethane) $/ \mathrm{HCl} \mathrm{pH}=7.9$, Q-sepharose column chromatography-purified (GE Healthcare, Munich, Germany) and column-bound complexing proteins were eluted. Antibodies against BoNT/A were immobilized on a $\mathrm{CNBr}$ sepharose matrix (GE Healthcare). BoNT/A was removed through affinity chromatography, eluted, and its composition checked for integrity.

\section{ELISA}

The amount of BoNT/A in pharmaceutical formulations of Botulax, Meditoxin, Nabota, or Relatox was measured in

Table I Properties of botulinum neurotoxin type A products analyzed in this study

\begin{tabular}{|c|c|c|c|c|c|c|}
\hline Product name & Innotox ${ }^{\circledR}$ & Botulax $^{\circledR}$ & $\begin{array}{l}\text { Meditoxin }{ }^{\circledR} / \\
\text { neuronox }^{\circledR}\end{array}$ & Nabota $^{\circledR}$ & Relatox $^{\circledR}$ & Xeomin $^{\circledR}$ \\
\hline Manufacturer & Medytox & Hugel Inc & Medytox Inc & Daewong & Microgen & Merz \\
\hline Dosage (U) & 25 & 100 & 100 & 100 & 100 & 100 \\
\hline Composition & Complex & Complex & Complex & $\begin{array}{l}\text { Complex } \\
(900 \mathrm{kDa}) \\
\end{array}$ & $\begin{array}{l}\text { Complex } \\
(900 \mathrm{kDa}) \\
\end{array}$ & Purified toxin $(150 \mathrm{kDa})$ \\
\hline Appearance & Liquid & Lyophilizate & Lyophilizate & Lyophilizate & Lyophilizate & Lyophilizate \\
\hline Formulation & $\begin{array}{l}\text { Polysorbate } \\
\text { (No HSA) }\end{array}$ & $\begin{array}{l}0.5 \mathrm{mg} \mathrm{HSA} ; \\
0.9 \mathrm{mg} \mathrm{NaCl}\end{array}$ & $\begin{array}{l}0.5 \mathrm{mg} \mathrm{HSA} ; \\
0.9 \mathrm{mg} \mathrm{NaCl}\end{array}$ & $\begin{array}{l}0.5 \mathrm{mg} \mathrm{HSA} ; \\
0.9 \mathrm{mg} \mathrm{NaCl}\end{array}$ & $\begin{array}{l}6 \mathrm{mg} \text { gelatine; } \\
12 \mathrm{mg} \text { maltose }\end{array}$ & $4.7 \mathrm{mg}$ sucrose; I mg HSA \\
\hline Storage & $2^{\circ} \mathrm{C}-8^{\circ} \mathrm{C}$ & $2^{\circ} \mathrm{C}-8^{\circ} \mathrm{C}$ & $2^{\circ} \mathrm{C}-8^{\circ} \mathrm{C}$ & $2^{\circ} \mathrm{C}-8^{\circ} \mathrm{C}$ & $2^{\circ} \mathrm{C}-8^{\circ} \mathrm{C}$ & Room temperature $\left(20^{\circ} \mathrm{C}-25^{\circ} \mathrm{C}\right)$ \\
\hline Clostridial protein per $100 \mathrm{U}(\mathrm{pg})$ & $\mathrm{N} / \mathrm{A}$ & $5,000^{12}$ & N/A & N/A & N/A & 416 \\
\hline
\end{tabular}

Notes: In other countries, Meditoxin is sold as Neuronox. As polysorbate prevents accurate ELISA readings, Innotox was not reported further in our work.

Abbreviations: ELISA, enzyme-linked immunosorbent assay; HSA, human serum albumin; N/A, information not publicly available. 
parallel with Xeomin using a sensitive sandwich ELISA with anti-150 kDa neurotoxin antisera raised in rabbit and guinea pigs. Coated microtiter plates were incubated with antisera diluted $1: 1,000$ in $100 \mathrm{mmol} / \mathrm{L}$ sodium carbonate, $\mathrm{pH}=9.5$. Except for the liquid Innotox formulation, two vials from the same batch of Botulax, Meditoxin, Nabota, Relatox, and Xeomin (from $100 \mathrm{U}$ vials each) were reconstituted with 1 $\mathrm{mL}$ of solution 1 . One hundred microliters of each preparation was analyzed in antisera-coated plates. Innotox was supplemented with human serum albumin to establish the reaction conditions validated for the ELISA. Each vial of reconstituted Botulax, Meditoxin, Nabota, Relatox, or liquid Innotox was analyzed in duplicate. Following incubation, the wells were washed with solution 1, and incubated with the guinea pig antiserum (1:2,000 dilution in solution 2). Unbound $150 \mathrm{kDa}$ neurotoxin antibodies were washed off. Anti-guinea pig immunoglobulin G peroxidase conjugate (1:5,000; Sigma, A7289) was used to detect bound antibodies by colorimetric quantification with o-phenylenediamine $(16 \mathrm{mmol} / \mathrm{L})$ in $10 \mathrm{mmol} / \mathrm{L}$ citrate buffer $(\mathrm{pH}=5.0)$. Optical density was measured at $490 \mathrm{~nm}$ using a microtiter plate reader and SoftMax Pro GxP (Spectra-Max Plus, Molecular Devices, San Jose, CA, USA). A standard curve of between 0.2 and $1.6 \mathrm{ng} / \mathrm{mL}$ of neurotoxin was produced in $0.2 \mathrm{ng} / \mathrm{mL}$ intervals (see Frevert $2010^{8}$ for representative standard curves). Internal controls were performed for each plate to ensure assay validity. Standard curve linearity and ELISA specificity, accuracy, and robustness were performed according to International Conference on Harmonisation guidelines. ${ }^{9}$ The ELISA was shown to be specific for the BoNT/A neurotoxin and did not detect complexing proteins.

\section{Results}

Table 1 describes the properties of Innotox, Botulax, Meditoxin, Nabota, and Relatox. ${ }^{10}$
Highly sensitive sandwich ELISA was used to quantify the amount of BoNT/A protein in Botulax, Meditoxin, Nabota, and Relatox (Table 2). Xeomin was independently analyzed in parallel as a control and found to have a mean toxin content of $416 \mathrm{pg} / \mathrm{vial}$, comparable to reports from another batch. ${ }^{8}$ It should be noted that this variation from published values is due to these batches of toxin being no longer available for the present analysis and the use of a different batch of Xeomin, as well as a 5\% intervial variability during the manufacturing process (unpublished data 2018, Merz Pharmaceuticals GmbH).

Botulax and Nabota contained 844 and 754 pg of neurotoxins, respectively, which are nearly twice the neurotoxin content of Xeomin (416 pg) in an equivalent $100 \mathrm{U}$ vial. However, the percentage of inactive neurotoxins was also calculated to be much higher at 103 and 81 , respectively, than that of Xeomin with no inactive neurotoxin. The potency per pg of neurotoxin in Botulax and Nabota was found to be 0.118 and $0.133 \mathrm{U}$, respectively. This was less potent than Xeomin's $0.240 \mathrm{U}$ per pg of neurotoxin. Meditoxin and Relatox contained 575 and 578 pg of neurotoxins, respectively, which were slightly higher than that of the Xeomin, as was the calculated percentage of inactive neurotoxins at 38 and 33, respectively. The efficacy per pg of neurotoxin in Meditoxin and Relatox was found to be 0.174 and $0.173 \mathrm{U}$, respectively, which were also lower than Xeomin's $0.240 \mathrm{U}$ of efficacy per pg of neurotoxin.

\section{Discussion}

All BoNT/A formulations contain the $150 \mathrm{kDa}$ neurotoxin, which is the active molecule. Xeomin, however, consists solely of the $150 \mathrm{kDa}$ neurotoxin. All products are based on the botulinum toxin complex with about sixfold more additional bacterial proteins, assuming a molecular weight of $\approx 900 \mathrm{kDa}$ for the complex. Some of the complexing proteins

Table 2 Determination of content of botulinum neurotoxin type A protein in products by ELISA

\begin{tabular}{llllll}
\hline Product name & Batch name & Dosage & $\begin{array}{l}\text { Amount of neurotoxin } \\
\text { protein per 100 units } \\
\text { (pg) }\end{array}$ & $\begin{array}{l}\text { Specific potency } \\
\text { (U/pg neurotoxin) }\end{array}$ & $\begin{array}{l}\text { Calculated } \\
\text { proportion (\%) of } \\
\text { inactive neurotoxin* }\end{array}$ \\
\hline Botulax $^{\circledR}$ & HUA I5I33 & $100 \mathrm{U} /$ vial (Lyo) & $844 \pm 43^{\ddagger}$ & 0.118 & 103 \\
\hline Meditoxin $^{\circledast / N e u r o n o x}{ }^{\circledR}$ & FAA I587 & $100 \mathrm{U} /$ vial (Lyo) & $575 \pm 6$ & 0.174 & 38 \\
\hline Nabota $^{\circledR}$ & 084962 & $100 \mathrm{U} /$ vial (Lyo) & $754 \pm 1 I^{\ddagger}$ & 0.133 & 81 \\
\hline Relatox $^{\circledR}$ & 0615 & $100 \mathrm{U} /$ vial (Lyo) & $578 \pm 48$ & 0.173 & 33 \\
\hline Xeomin $^{\circledR}$ & 31149 & $100 \mathrm{U} /$ vial (Lyo) & $416 \pm 6$ & 0.240 & Not found \\
\hline
\end{tabular}

Notes: Innotox ${ }^{\circledR}$ (not reported in this table) contains the surfactant polysorbate, ${ }^{25}$ which can interfere with antibody-antigen binding during ELISA and lead to inaccurate and low concentrations. Innotox's toxin content, therefore, could not be accurately measured using standard ELISA, which is validated for experimental conditions without polysorbate. *Calculation based on claim that Xeomin contains only the active neurotoxin $(=100 \%)$; $¥$ Value above standard curve.

Abbreviations: ELISA, enzyme-linked immunosorbent assay; Lyo: lyophilized. 
are hemagglutinins, which are glycoprotein binding proteins (so-called lectins). In contrast to the $150 \mathrm{kDa}$ neurotoxin, these complexing proteins have the potential to bind to dendritic cells, ${ }^{11,14}$ the sentinel cells of the immune system. These cells must be activated as the first step of the initiation of an immune response. ${ }^{12,14}$ In this regard, complexing protein-containing products have a higher potential to cause an immune response. Indeed, the formation of antibodies in patients treated with complexing protein-containing products in esthetic medicine has been reported. ${ }^{7}$ In contrast, antibody formation was not observed in patients treated with Xeomin free of complexing proteins. A further important factor determining the potential for immunogenicity of BoNT/A formulations and subsequent treatment failure is the amount of neurotoxin protein present. 5,15 This is associated with increased antigen levels and, consequently, a greater risk of antibody production. ${ }^{16}$ It was demonstrated in cervical dystonia patients treated with BoNT products that the specific potency (U per pg neurotoxin) is correlated with the antibody-induced therapy failure. ${ }^{17}$ It is, therefore, helpful for the clinician to receive information about the specific potency of different botulinum toxin products.

Currently, BoNT/A preparations approved for several indications in adults in Asia, Europe, and the USA include onabotulinumtoxinA (Allergan Inc., Irvine, CA, USA; also known as Botox ${ }^{\circledR}$ or Vistabel ${ }^{\circledR}$ ), abobotulinumtoxinA (Ipsen Ltd, Slough, UK/Galderma, Paris, France; also known as Dysport $^{\circledR}$ or Azzalure ${ }^{\circledR}$ ), and incobotulinumtoxinA (Merz Pharmaceuticals GmbH, Reinheim, Germany; also known as Xeomin or Bocouture ${ }^{\circledR}$ ), each of which is uniquely formulated. These variable manufacturing, formulation, and testing processes have produced preparations with different potency, dosage, constituents, and immunogenicity. ${ }^{18,19}$

As Xeomin's manufacturing process isolates only the active $150 \mathrm{kDa}$ neurotoxin, Xeomin is entirely free of complexing protein. ${ }^{20}$ Besides the active $150 \mathrm{kDa}$ neurotoxin, Botox and Dysport contain complexing proteins that form a high-molecular-weight complex with the $150 \mathrm{kDa}$ neurotoxin. That is, Botox comprises one $150 \mathrm{kDa}$ neurotoxin molecule within a $900 \mathrm{kDa}$ protein complex. ${ }^{21}$ Although Dysport's precise biochemical composition remains undefined, it is also likely to contain the $500-600 \mathrm{kDa}$ L-complex protein within the $900 \mathrm{kDa}$ complex protein as well. ${ }^{22}$ Xeomin/Bocouture remains the only BoNT/A product marketed as containing "purified neurotoxin" that has been registered with regulatory authorities in the USA and Europe.

As reported, Botox contains 5,000 pg of toxin per 100 $\mathrm{U}$ vial $^{23}$ (including complexing proteins), Dysport contains
4,350 pg of toxin (including complexing proteins) per $500 \mathrm{U}$ vial, ${ }^{24}$ and Xeomin contains 440 pg of neurotoxin per $100 \mathrm{U}$ vial. ${ }^{8}$ Here, the mean concentration of BoNT/A neurotoxin was $730 \mathrm{pg}$ in a $100 \mathrm{U}$ vial of Botox (batches C2344C3, C2384C3, C2419, and C2385), $650 \mathrm{pg}$ in a $100 \mathrm{U}$ vial of Dysport (batches 678F and 689X), and $440 \mathrm{pg}$ in $100 \mathrm{U}$ vials of Xeomin (batches 61,111, 70,604, and 81,208). ${ }^{8}$ The specific potency, defined as the potency in units associated with a specified amount of the $150 \mathrm{kDa}$ toxin in each product, was $0.137 \mathrm{U} / \mathrm{pg}$ for Botox, $0.154 \mathrm{U} / \mathrm{pg}$ for Dysport, and $0.227 \mathrm{U} / \mathrm{pg}$ for Xeomin, ${ }^{8}$ which suggested that Xeomin was the most potent because it has the highest amount of toxin protein among those tested.

Comparing the different products, Botulax and Nabota showed a similar specific potency with 0.118 and $0.133 \mathrm{U} /$ pg, respectively. Meditoxin and Relatox have less neurotoxin protein than Botulax and Nabota but higher specific potencies $(0.174$ and $0.173 \mathrm{U} / \mathrm{pg})$. However, their specific potencies are lower than that of Xeomin $(0.240 \mathrm{U} / \mathrm{pg})$. One can conclude that the lower specific potency of Botulax, Nabota, Meditoxin, and Relatox may actually indicate the presence of significant amounts of inactive, rather than active, neurotoxin. Thus, high neurotoxin protein levels detected in this study were not due to biologically efficacious neurotoxin, but due to inactive toxin provided that all products were equipotent in containing $100 \mathrm{U}$ per vial. This inactive neurotoxin cannot be taken up by neurons but might represent an immunogenic impurity. ${ }^{17}$ These inactive components, which have no clinical efficacy, per se, may stimulate antibody production. ${ }^{11}$ They can reduce the efficacy of the neurotoxin by inducing immunoreactions in patients who then need to receive a higher dosage at later sessions, ultimately increasing their risk of becoming nonresponders.

\section{Conclusion}

Four BoNT/A formulations being used in Asia have shown lower neurotoxin purity and specific potency but higher neurotoxin protein concentrations than Xeomin in this study. Although Botulax and Nabota had more neurotoxin than Xeomin in an equivalent volume, they contained greater amounts of inactive neurotoxin. In addition, although Meditoxin and Relatox had slightly more neurotoxin than Xeomin, both contained greater amounts of inactive neurotoxin. In the future, it will be necessary to conduct a comparative study on the efficacy, effective duration, and safety profile of all neurotoxin products, particularly on the incidence of secondary treatment failures due to antibody formation in patients undergoing long-term treatment with BoNT/A. 


\section{Authors contribution}

All authors contributed toward data analysis, drafting and revising the paper and agree to be accountable for all aspects of the work.

\section{Disclosure}

JF and OS are employee of Merz Pharmaceuticals. The authors report no other conflicts of interest in this work.

\section{References}

1. Baker MP, Reynolds HM, Lumicisi B, Bryson CJ. Immunogenicity of protein therapeutics: the key causes, consequences and challenges. Self Nonself. 2010;1(4):314-322.

2. Joshi SG, Elias M, Singh A, et al. Modulation of botulinum toxin-induced changes in neuromuscular function with antibodies directed against recombinant polypeptides or fragments. Neuroscience. 2011;179: 208-222.

3. Pless DD, Torres ER, Reinke EK, Bavari S. High-affinity, protective antibodies to the binding domain of botulinum neurotoxin type A. Infect Immun. 2001;69(1):570-574.

4. Jankovic J, Schwartz K. Response and immunoresistance to botulinum toxin injections. Neurology. 1995;45:1743-1746.

5. Torres S, Hamilton M, Sanches E, Starovatova P, Gubanova E, Reshetnikova T. Neutralizing antibodies to botulinum neurotoxin type A in aesthetic medicine: five case reports. Clin Cosmet Investig Dermatol. 2014;7:11-17.

6. Walker TJ, Dayan SH. Comparison and overview of currently available neurotoxins. J Clin Aesthet Dermatol. 2014;7(2):31-39.

7. DasGupta BR, Sathyamoorthy V. Purification and amino acid composition of type A botulinum neurotoxin. Toxicon. 1984;22:415-424.

8. Frevert J. Content of botulinum neurotoxin in Botox ${ }^{\circledR} /$ Vistabel $^{\circledR}$, ${\text { Dysport }{ }^{\circledR} / \text { Azzalure }}^{\circledR}$, and Xeomin ${ }^{\circledR} /$ Bocouture $^{\circledR}$. Drugs $R D$. 2010;10(2):67-73.

9. International Conference on Harmonization Guideline. Q2B Validation of Analytical Procedures: Methodology. November 1996, ICH. Available from: https://www.ich.org/fileadmin/Public_Web_Site/ICH_Products/ Guidelines/Quality/Q2_R1/Step4/Q2_R1_Guideline.pdf. Accessed June 15, 2018.
10. Yang GH, Jung HH. A new botulinum toxin potentially bioequivalent to onabotulinumtoxin A: are there any differences at all? Dermatol Surg. 2013;39:165-170.

11. Lam SM. The basic science of botulinum toxin. Facial Plast Surg Clin NAm. 2003;11:431-438.

12. HUGEL Pharma. 2014-11-06. Botulax Botulinum Toxin Type A Brochure. Korea. n.p.

13. Sharon N, Lis $\mathrm{H}$. History of lectins: from hemagglutinins to biological recognition molecules. Glycobiology. 2004;14:53R-62R.

14. Wang L, Sun Y, Yang W, et al. Type A botulinum neurotoxin complex proteins differentially modulate host response of neuronal cells. Toxicon. 2014;82:52-60.

15. Stengel G, Bee E. Antibody-induced secondary treatment failure in a patient treated with botulinum toxin type A for glabellar frown lines. Clin Interv Aging. 2011;6:281-284.

16. Naumann M, Boo LM, Ackerman AH, Gallagher CJ. Immunogenicity of botulinum toxins. J Neural Transm (Vienna). 2013;120(2):275-290.

17. Dressler D. IncobotulinumtoxinA (Xeomin $\left.{ }^{\circledR}\right)$. In: Stacy MA, editor. Handbook of Dystonia. New York (NY): Informa Healthcare; 2012:469-476.

18. Dessy LA, Fallico N, Mazzocchi M, Scuderi N. Botulinum toxin for glabellar lines: a review of the efficacy and safety of currently available products. Am J Clin Dermatol. 2011;12:377-388.

19. Brin MF, James C, Maltman J. Botulinum toxin type A products are not interchangeable: a review of the evidence. Biologics. 2014;8:227-241.

20. Jimenez-Shahed J. A new treatment for focal dystonias: incobotulinumtoxin A (Xeomin ${ }^{\circledR}$ ), a botulinum neurotoxin type A free from complexing proteins. Neuropsychiatr Dis Treat. 2012;8:13-25.

21. Schantz EJ, Johnson EA. Properties and use of botulinum toxin and other microbial neurotoxins in medicine. Microbiol Rev. 1992;56(1):80-99.

22. Hambleton P. Clostridium botulinum toxins: a general review of involvement in disease, structure, mode of action and preparation for clinical use. J Neurol. 1992;239(1):16-20.

23. Allergan Inc. BOTOX ${ }^{\circledR}$ (BotulinumtoxintypeA) purified neurotoxin complex: prescribing information revised March 2010 [online]. Available from: http://www.allergan. com/assets/pdf/botox_pi.pdf. Accessed May 28, 2016

24. Panjwani N, O'Keeffe R, Pickett A. Biochemical, functional and potency characteristics of type A botulinum toxin in clinical use. The Botulinum J. 2008;1(1):153-166.

25. Seo KK. Innotox ${ }^{\circledR}$ : "Botulinum toxin endorsed by BOTOX ${ }^{\circledR}$ ". In: Seo KK, editor. Botulinum Toxin for Asians. 1st ed. Singapore: Springer Science+Business Media; 2017:19.
Clinical, Cosmetic and Investigational Dermatology

\section{Publish your work in this journal}

Clinical, Cosmetic and Investigational Dermatology is an international, peer-reviewed, open access, online journal that focuses on the latest clinical and experimental research in all aspects of skin disease and cosmetic interventions. This journal is included on PubMed. The manuscript management system is completely online

\section{Dovepress}

and includes a very quick and fair peer-review system, which is all easy to use. Visit http://www.dovepress.com/testimonials.php to read real quotes from published authors 